\title{
Debris flow and landslide processes on manmade landscapes
}

\author{
Darya Bobrova ${ }^{1, *}$, Ekaterina Kazakova ${ }^{1}$, Svetlana Rybalchenko $^{1}$, and Sergei Kudriavtcev ${ }^{2}$ \\ ${ }^{1}$ Special Research Bureau for Automation of Marine Researches, Far Eastern Branch of Russian \\ Academy of Sciences, Russia \\ ${ }^{2}$ Far Eastern State Transport University (FESTU), Serysheva str., 47, Khabarovsk, 680021, Russia
}

\begin{abstract}
Currently the human activity is one of the important factors of debris flow and landslide formation. In some cases, human activity leads to the formation of previously non-existing debris flow and landslide complexes, which increases the areal percentage of exposure of settlement areas to dangerous processes. Most often, anthropogenic debris flows and landslides are confined to the mountainous territory, which is associated with the extraction of minerals, road construction, construction of buildings and structures and storage of soil in floodplains and watercourses on weak mountain slopes. The authors propose to divide the anthropogenic genetic class of debris flows and landslides into three categories, depending on the degree of influence of anthropogenic activity on the formation of debris flow and landslide processes and their characteristics. The usage of this classification allows to determine and evaluate possible consequences of debris flows and landslides at the early stages of economic activity planning
\end{abstract}

\section{Introduction}

Human activity leads to changes in natural landscapes, which leads to the activation of dangerous geological processes, including debris flows and landslides. In some cases, the creation of new, previously non-existent, anthropogenic landscapes, which include artificially created forms of relief (dumps, various embankments and recesses, quarries, etc.) becomes the cause of new debris flows and landslide complexes. The creation of such manmade complexes increases the areal percentage of exposure of settlement areas to dangerous processes.

The dangerous processes development in the anthropogenically-modified landscapes is possible in all regions, where they are confined to the construction of buildings and structures, road construction, and are mainly associated with the excavation and storage of soil, the formation of road embankments, undercutting of slopes. However, they are most widespread in mountainous areas, and are associated with the extraction of minerals, storage of mining dumps. In conditions of mountainous terrain, most of the soil dumps are located in floodplains and riverbeds and streams on weak mountain slopes, which can lead to the formation of multi-stage or chain natural and man-made disasters: landslide $\rightarrow$ overlap of the

* Corresponding author: darya-kononova@yandex.ru 
riverbed or valley $\rightarrow$ flooding of the territory and the formation of an artificial reservoir $\rightarrow$ breakthrough of an artificial reservoir $\rightarrow$ catastrophic debris flow [3].

An example of hazardous exogenous geological processes in anthropogenically modified landscapes is the formation of a catastrophic landslide at the dump coal deposit cut "Zarechnyjj" (Kemerovo region), which took place on 01 April 2015. The volume of the landslide was 27 million $\mathrm{m}^{3}$. As a result of the landslide, there was damage to power lines, destruction of a section of the road, the access railway of Taldinsky technical vocational school, as well as the overlap of The Kyrgai river bed.

One of the regions with a high degree of dangerous exogenous geological processes is Sakhalin Island. In addition, currently the Sakhalin Island is at the stage of active economic development, which often leads to the emergence of natural and man-made disasters.

Thus, landslides and debris flows are formed almost annually in various parts of the island from the soil dumps of mining enterprises. One of such cases was recorded on 20 July 2009 by employees of the Sakhalin Branch of the Far East Geological Institute of the Far Eastern Branch of the Russian Academy of Science: man-made debris flow was formed from the dump of the quarry "Listvenichnyi", located on the slope of the Medica mountain (Susunaisky Ridge). Formation of small debris flows $\left(0.5-1\right.$ thousand $\left.\mathrm{m}^{3}\right)$ from the dump of this quarry is noted regularly, but in recent years, due to the intensive development of the quarry and the increase in the volume of exported waste rock for storage, two cases of formation of large debris flows have been recorded: 10 thousand $\mathrm{m}^{3} 3$ and 15 thousand $\mathrm{m}^{3}$ (2009 and 2013, respectively). The total volume of debris flow deposits in the valley of the nameless stream is approximately 55 thousand $\mathrm{m}^{3}$. These debris flows destroyed 3.5 hectares of forest [1] (Fig. 1).

One of the last cases of landslides formation from the dumps is the descent of the landslide-flow from the dump of rocks of the coal-mining quarry in the village of Gornozavodsk of the Nevelsky district on the South-West coast of Sakhalin island on may 14, 2018, as a result of which a private house and farm buildings were destroyed (Fig. 2).

On April 15-16, 2018, a landslide was formed on the South-West coast of Sakhalin island on the section of the Federal highway of Yuzhno-Sakhalinsk - Kholmsk in the area of the domestic waste landfill of Kholmsk. The reasons for activation - overload of the soil dump formed during the construction of the road, construction waste and household waste, as well as intensive watering of the blade during snow melting (Fig. 3).

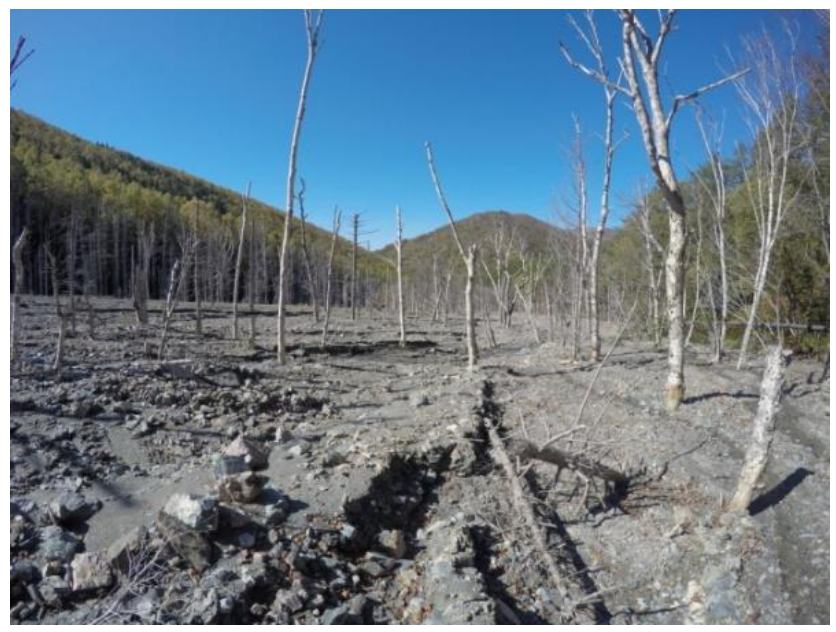

Fig. 1. Debris flow deposit of technogenic debris-flow, created from soil of a dump of a pit «Listvennichny» in river channel of tributary of the Chomutovka River, 2016. Photo of authors. 


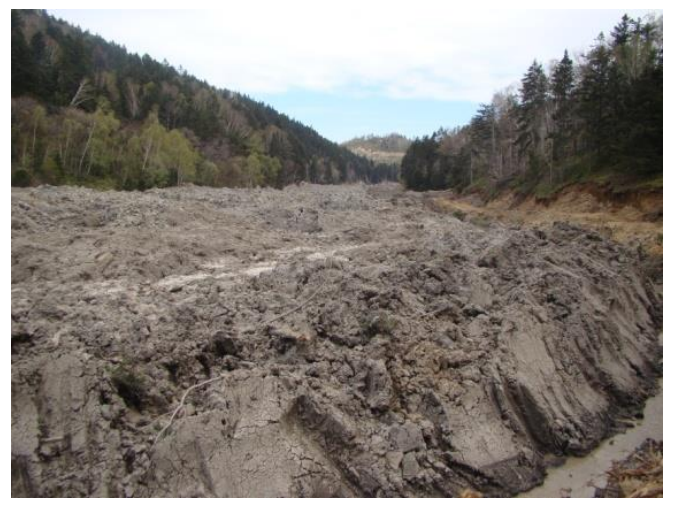

Fig. 2. Landslide deposit of technogenic soil of a dump coal producer in village Gornozavodsk, Nevelskiy district, May 14, 2018. Photo of the authors.

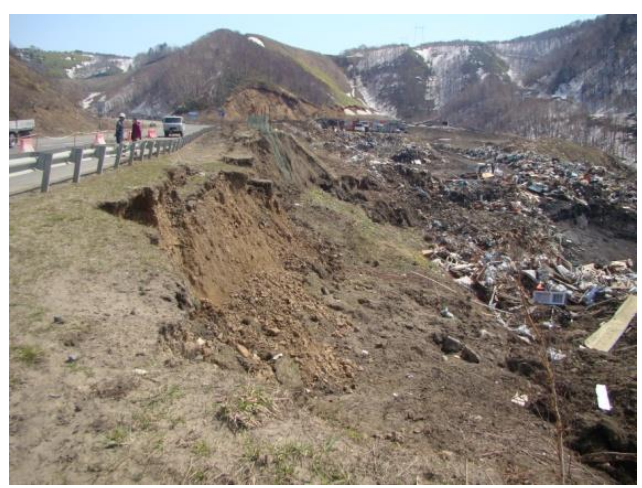

Fig. 3. Landslide in the area of the solid waste landfill in Kholmsk on the Yuzhno-SakhalinskKholmsk highway, April 2018. Photo of the authors.

Thus, dumps, various embankments and recesses, quarry are the source of landslides and mudslides.

\section{Anthropogenic genetic class of dangerous slope processes}

At present, in connection with anthropogenic activity, a separate genetic class of dangerous exogenic processes is distinguished - anthropogenic [2]. Depending on the degree of influence of anthropogenic activity on the formation of dangerous slope gravity processes within this class, it is possible to distinguish three categories of activity that affect their formation and characteristics to varying degrees. In turn, categories of anthropogenic impact are divided into activities (Fig. 3).

1. Formation - the creation of new landslide and debris flow complexes by man.

2. Transformation - impact on natural landslide and debris flow complexes, directly in which anthropogenic activity leads to a change (decrease or increase) in the characteristics of dangerous slope processes.

3. Indirect impact - the implementation of anthropogenic activities in neighboring areas landslide and debris flow areas, which leads to changes (decrease or increase) in the characteristics of dangerous slope processes.

Depending on the type of impact, changes in the characteristics affecting the parameters of dangerous slope processes, which determine the nature and extent of the impact of these processes on the population and economy. 


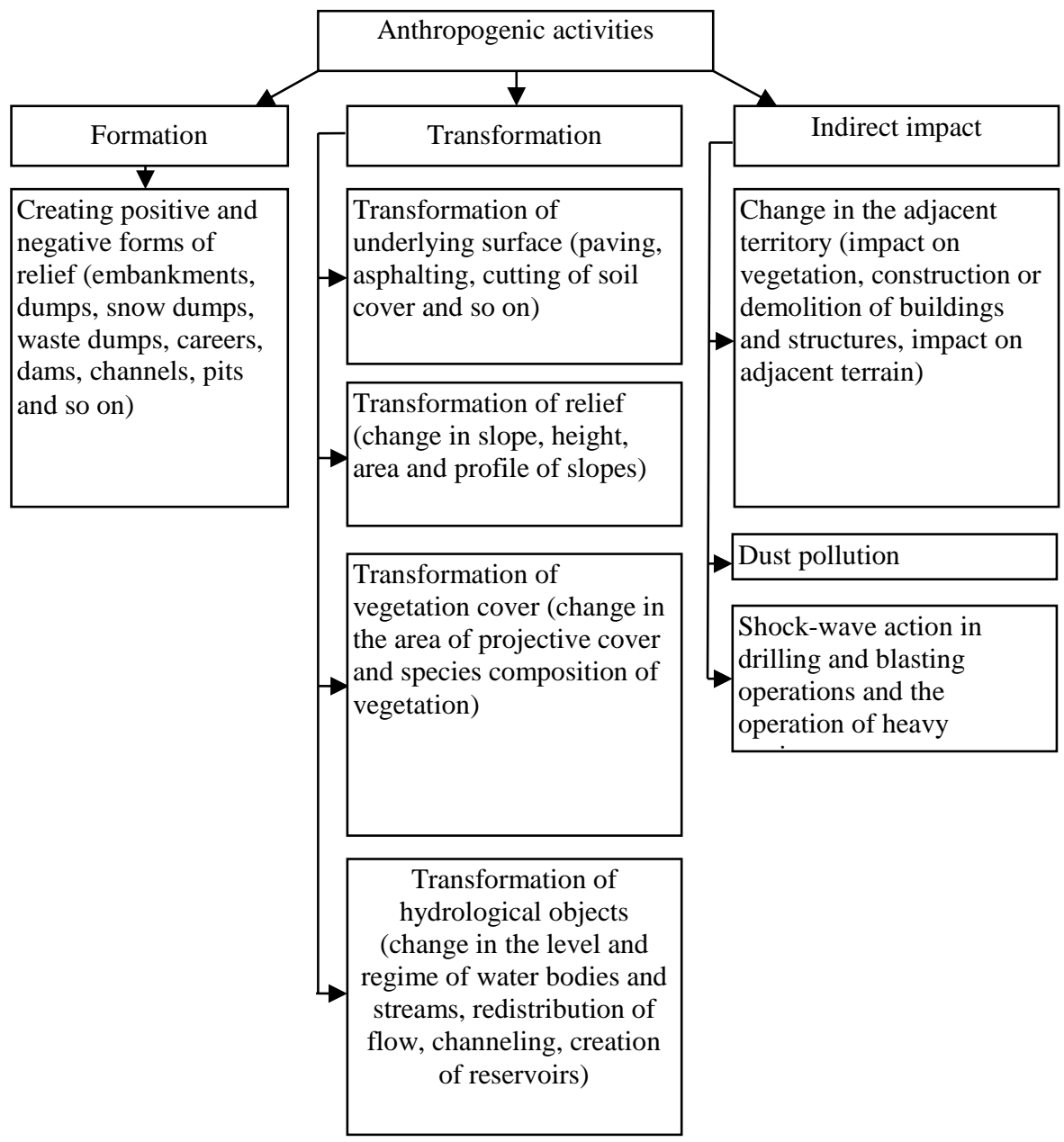

Fig. 4. Categories and types of impact on debris flow and landslide processes.

Such parameters for debris flow and landslide processes are spatial percentage of areas affected, dynamic characteristics, frequency of formation, volumes. Also, anthropogenic activity can influence the activation of dangerous sloping processes (Table 1).

It is worth noting that the degree of influence on dangerous slope processes will also be determined by the area in which the debris flow and landslide complexes are operating (for example, the zone of origin, transit or accumulation of the debris flow). Thus, the reduction of vegetation in the origin zone of debris flow will affect the change in velocity of rock weathering, change in the regime and rate of humidification of rocks, while the reduction of vegetation in the transit zone and the accumulation zone will not affect these processes, but will determine the dynamic characteristics of the debris flow. Within the framework of this work, the division of the character and the degree of anthropogenic activity, depending on the areas of the debris flow and landslide complex, was not carried out.

Quantitative parameters of the characteristics and parameters of debris flow and landslide processes are not given in the work, since their change will depend on the scale of anthropogenic impact and the zones of debris flow and landslide complexes in which anthropogenic activity is carried out. 
Table 1. Change in characteristics and parameters of debris flow and landslide processes under different types of anthropogenic activity.

\begin{tabular}{|c|c|c|c|c|}
\hline $\begin{array}{c}\text { Category } \\
\text { of activity }\end{array}$ & $\begin{array}{l}\text { Type of } \\
\text { activity }\end{array}$ & $\begin{array}{l}\text { Change in characteristics that } \\
\text { affect process parameters }\end{array}$ & \begin{tabular}{|c|}
$\begin{array}{c}\text { Change in parameters of } \\
\text { debris flow processes }\end{array}$ \\
\end{tabular} & $\begin{array}{c}\text { Change in parameters of } \\
\text { landslide processes }\end{array}$ \\
\hline Formation & $\begin{array}{l}\text { Creating new } \\
\text { forms of relief }\end{array}$ & $\begin{array}{l}\text { Change in the number of flow } \\
\text { and landslide complexes }\end{array}$ & $\begin{array}{l}\text { Change in spatial } \\
\text { percentage of areas } \\
\text { affected }\end{array}$ & $\begin{array}{l}\text { Change in spatial } \\
\text { percentage of areas } \\
\text { affected }\end{array}$ \\
\hline \multirow{4}{*}{ 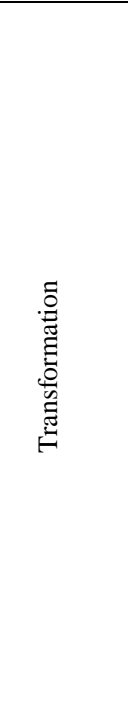 } & $\begin{array}{l}\text { Transformation } \\
\text { of underlying } \\
\text { surface }\end{array}$ & $\begin{array}{l}\text { The change in the roughness of } \\
\text { the underlying surface; change } \\
\text { in velocity of rock weathering; } \\
\text { change in the regime and rate } \\
\text { of humidification } \\
\text { of rocks. }\end{array}$ & $\begin{array}{l}\text { Dynamic characteristics } \\
\text { change }\end{array}$ & - \\
\hline & $\begin{array}{l}\text { Transformation } \\
\text { of relief }\end{array}$ & $\begin{array}{l}\text { Change in slope, height, area } \\
\text { and profile of slopes }\end{array}$ & $\begin{array}{l}\text { Changing the frequency } \\
\text { of formation; dynamic } \\
\text { characteristics change; } \\
\text { change in volume }\end{array}$ & $\begin{array}{l}\text { Dynamic characteristics } \\
\text { change; change in } \\
\text { volume; activation or } \\
\text { stabilization of the } \\
\text { process }\end{array}$ \\
\hline & $\begin{array}{l}\text { Transformation } \\
\text { of vegetation } \\
\text { cover }\end{array}$ & $\begin{array}{l}\text { The change in the roughness of } \\
\text { the underlying surface; change } \\
\text { in velocity of rock weathering; } \\
\text { change in the regime and rate } \\
\text { of humidification } \\
\text { of rocks; change in wind speed } \\
\text { and direction }\end{array}$ & $\begin{array}{l}\text { Changing the frequency } \\
\text { of formation; dynamic } \\
\text { characteristics change; } \\
\text { change in volume }\end{array}$ & $\begin{array}{l}\text { Changing the frequency } \\
\text { of formation }\end{array}$ \\
\hline & $\begin{array}{l}\text { Transformation } \\
\text { of hydrological } \\
\text { objects }\end{array}$ & $\begin{array}{l}\text { Change in the regime and rate } \\
\text { of humidification } \\
\text { of rocks }\end{array}$ & $\begin{array}{l}\text { Changing the frequency } \\
\text { of formation; dynamic } \\
\text { characteristics change; } \\
\text { change in volume }\end{array}$ & $\begin{array}{l}\text { Activation or } \\
\text { stabilization of the } \\
\text { process }\end{array}$ \\
\hline \multirow{3}{*}{ 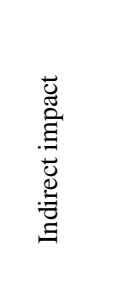 } & $\begin{array}{l}\text { Change in the } \\
\text { adjacent } \\
\text { territory }\end{array}$ & $\begin{array}{l}\text { Change in the regime and rate } \\
\text { of humidification } \\
\text { of rocks; change in wind speed } \\
\text { and direction }\end{array}$ & $\begin{array}{l}\text { Changing the frequency } \\
\text { of formation; dynamic } \\
\text { characteristics change; } \\
\text { change in volume }\end{array}$ & $\begin{array}{l}\text { Activation or } \\
\text { stabilization of the } \\
\text { process }\end{array}$ \\
\hline & $\begin{array}{l}\text { Dust pollution } \\
\text { Of territory }\end{array}$ & Decrease in albedo of a surface & $\begin{array}{l}\text { Changing the frequency } \\
\text { of formation }\end{array}$ & $\begin{array}{l}\text { Changing the frequency } \\
\text { of formation }\end{array}$ \\
\hline & $\begin{array}{l}\text { Shock-wave } \\
\text { action }\end{array}$ & Decompaction of rocks & Change in volume & Change in volume \\
\hline
\end{tabular}

\section{Conclusion}

Depending on the degree of influence of anthropogenic activity on the formation of debris flows and landslides, three categories of activity can be distinguished: formation, transformation and indirect impact. Each category is divided into types of impact, depending on which there is a change in those or other characteristics of mudflow and landslide processes. At the initial stage of planning economic activity on the basis of the developed classification it is possible to determine the likely consequences for the population of manifestations of mudflow and landslide processes.

\section{References}

1. A.A. Muzychenko, V.S. Pavlov, A. Pavlov, Dal'nauka Vladivostok 2, 346-349 (2015)

2. V.F. Perov, Selevedenie (MSU, Moscow, 2012)

3. S.V. Rybal'chenko, Dal'nauka Vladivostok, 34, 195-197 (2008) 